\title{
Oxidative protein labeling in mass-spectrometry-based proteomics
}

\author{
Julien Roeser • Rainer Bischoff • Andries P. Bruins • \\ Hjalmar P. Permentier
}

Received: 30 October 2009 /Revised: 11 January 2010 /Accepted: 12 January 2010 /Published online: 13 February 2010

(C) The Author(s) 2010. This article is published with open access at Springerlink.com

\begin{abstract}
Oxidation of proteins and peptides is a common phenomenon, and can be employed as a labeling technique for mass-spectrometry-based proteomics. Nonspecific oxidative labeling methods can modify almost any amino acid residue in a protein or only surface-exposed regions. Specific agents may label reactive functional groups in amino acids, primarily cysteine, methionine, tyrosine, and tryptophan. Nonspecific radical intermediates (reactive oxygen, nitrogen, or halogen species) can be produced by chemical, photochemical, electrochemical, or enzymatic methods. More targeted oxidation can be achieved by chemical reagents but also by direct electrochemical oxidation, which opens the way to instrumental labeling methods. Oxidative labeling of amino acids in the context of liquid chromatography(LC)-mass spectrometry (MS) based proteomics allows for differential LC separation, improved MS ionization, and label-specific fragmentation and detection. Oxidation of proteins can create new reactive groups which are useful for secondary, more conventional derivatization reactions with, e.g., fluorescent labels. This review summarizes reactions of oxidizing agents with peptides and proteins, the corresponding methodologies and instrumentation, and the major, innovative applications of oxidative protein labeling described in selected literature from the last decade.
\end{abstract}

Keywords Protein oxidation $\cdot$ Radical $\cdot$ Protein footprinting $\cdot$ Peptide cleavage

J. Roeser $\cdot$ R. Bischoff • A. P. Bruins $\cdot$ H. P. Permentier $(\bowtie)$ Analytical Biochemistry and Mass Spectrometry Core Facility, Department of Pharmacy, University of Groningen,

A. Deusinglaan 1,

9713 AV Groningen, The Netherlands

e-mail: h.p.permentier@rug.nl

\section{Introduction}

The development of analytical methods for oxidatively modified amino acid residues has benefited from the study of oxidative damage to proteins related to ageing and disease $[1,2]$. This review focuses on applications of oxidative protein labeling in mass-spectrometry (MS)-based proteomics.

Proteomics experiments typically aim at the identification and subsequent quantitation of as many proteins as possible in a sample. Often, however, a subset of proteins of interest needs to be quantified, for example, as potential biomarkers. Labeling, whether oxidative or nonoxidative, changes properties of peptides and proteins, which can be used to improve sample cleanup, high performance liquid chromatography (HPLC) separation, MS detection, and quantitation. A labeling method can be tailored to enhance detection of target proteins or peptides and/or suppress signals from undesired or uninteresting ones. For example, through the labeling of Nterminal peptides, sample complexity is greatly reduced [3], whereas important details about protein processing are revealed.

The main targets for derivatization in proteomics are amines [protein or peptide N-terminus and lysine (Lys)] and thiols [cysteine (Cys)], for which numerous specific labeling methods are known. Oxidative derivatization primarily targets redox-sensitive residues, comprising the aromatic tryptophan (Trp), tyrosine (Tyr), phenylalanine (Phe), and histidine (His) residues and the sulfur-containing Cys and methionine (Met) residues (Fig. 1). Although thiols are usually labeled through nonoxidative electrophilic substitution reactions, disulfide bond formation between two thiol groups can be promoted by oxidizing agents and is a common and reversible labeling method. 
Fig. 1 Structures of the most common amino acid oxidation products. $X$ denotes either a halogen or a hydroxyl group tyrosine
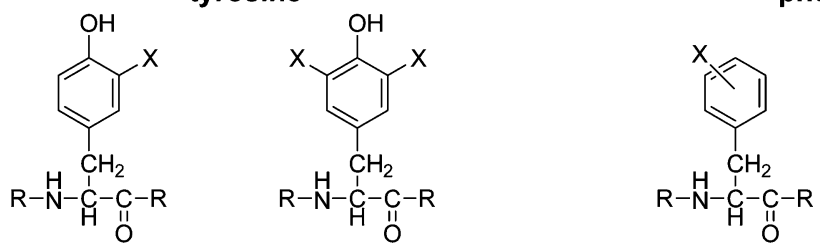

phenylalanine

tryptophan

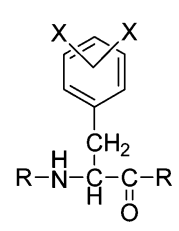

histidine
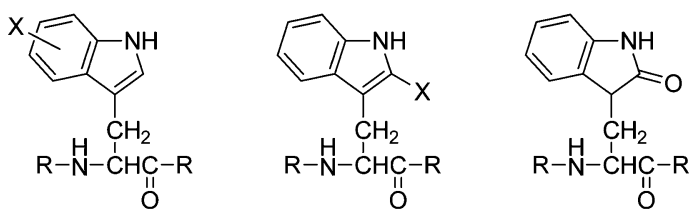

2-oxo-tryptophan

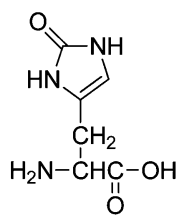

2-oxo-histidine

\section{methionine}

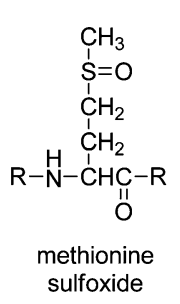

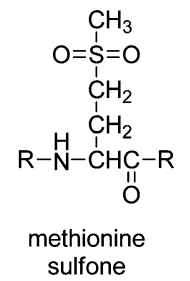

cysteine

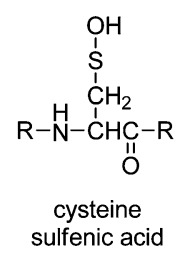

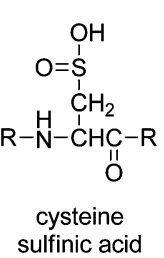

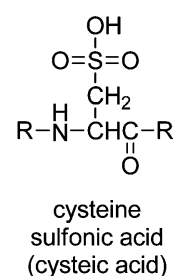

For oxidative labeling reactions a distinction is made between primary (direct) oxidation of amino acid residues followed by reaction with nucleophiles (e.g., electrochemical oxidation of Tyr followed by reaction with water) and reaction with oxidizing reagents (e.g., hydroxyl radicals). For aromatic residues such as Tyr and Trp the distinction between oxidation and electrophilic aromatic substitution is not always clear. Different reactions can result in the same products via different intermediates (e.g., via hydroxylation or halogenation of the aromatic rings).

Oxidative labeling is presented here as a distinct category of labeling techniques, based on the specific methods employed and the fact that less commonly targeted redox-active residues are modified. In contrast to regular chemical labeling methods, reactive intermediates of either the reactant or the target protein are formed by oxidation. Oxidative labeling is the most straightforward labeling method for aromatic residues, in particular Tyr and Trp, and provides access to purely instrumental labeling methods, such as electrochemical oxidation, which has no equivalent in conventional, chemical labeling methods. Electrochemical oxidation can be achieved with a stand-alone electrochemical cell but the electrospray emitter itself can also act as an electrode in the case of online liquid chromatography (LC)-electrospray-MS analysis.

The following sections present and discuss the main reactive agents, their production methods, and their most common reactions with peptides and proteins, illustrating various applications of oxidative labeling in MS-based proteomics.

\section{Methods for oxidative modification}

A distinction can be made between nonspecific labeling reactions and reactions directed at specific amino acids or functional groups. The directed reactions are used for sitespecific labeling, whereas less specific methods, notably those mediated by free radicals (e.g., hydroxyl radicals), are useful for accessibility-based labeling to probe the threedimensional structure of proteins (see "Applications"). However, studies have shown that amino acids with redox-active side chains are more susceptible than others [4]. Nonspecific labeling reactions are also widely used for mimicking in vivo oxidation (e.g., susceptibility to oxidants generated during a host defense reaction).

\section{Oxidation agents and reaction with peptides and proteins}

In this section, a review of the most widely used oxidizing agents is presented and the primary end products are listed with selected examples taken from the literature. Oxidizing agents are grouped in three main categories, namely, 
reactive oxygen species (ROS), reactive nitrogen species (RNS), and reactive halogen species.

\section{Reactive oxygen species}

ROS-mediated oxidation of amino acids in proteins is an important process occurring in vivo as part of the first-line defense of a host organism against infections [5-7]. ROSmediated protein modification has therefore been extensively studied by biologists and biochemists owing to its implication in disease development [1, 2]. ROS include hydroxyl radicals $\left(\mathrm{OH}^{\bullet}\right)$, superoxide anions $\left(\mathrm{O}_{2}{ }^{-\bullet}\right)$, peroxides (ROOR, including radical species derived from them), and ozone $\left(\mathrm{O}_{3}\right)$. The effect of ROS on free amino acids and amino acid residues in proteins has been extensively studied and reviewed by Garrison [8] and more recently by Stadtman and Levine [9]. Typically, the study of ROS-mediated oxidation of proteins can be performed by generating the reactive species by chemical, photochemical, enzymatic, or electrochemical reactions of molecular oxygen $\left(\mathrm{O}_{2}\right)$, hydrogen peroxide $\left(\mathrm{H}_{2} \mathrm{O}_{2}\right)$, or water $\left(\mathrm{H}_{2} \mathrm{O}\right)$.

Hydroxyl radicals are by far the most commonly studied ROS. They can easily be generated (see "Production and use of oxidation agents"), and they have a broad range of reactivity, which includes not only the oxidation-sensitive Cys, Met, Trp, Tyr, Phe, and His side chains, but also aliphatic groups and the peptide backbone [4, 9]. Hydroxyl radicals can abstract electrons from the alpha carbon of any amino acid to form carbon radicals [4], which after reaction with $\mathrm{O}_{2}$ leads to peptide backbone cleavage. Alternatively beta-carbon radical formation leads to beta-scission, resulting in side chain cleavage [10]. Covalent modification of the side chains of aromatic amino acids by hydroxyl radicals results most commonly in hydroxylation (Fig. 1). Phe is converted to 2-hydroxy-Phe, 3-hydroxy-Phe, and 4-hydroxy-Phe, whereas Tyr yields mainly the ortho-hydroxylation product [11]. Tyr can also undergo cross-linking reactions to form dityrosine derivatives [12]. Trp residues are converted to a mixture of hydroxy-Trp isomers followed by further decomposition to kynurenine by a pyrrole ring opening reaction [13].

Ozone, as a powerful oxidizing agent, was shown to react with free amino acids and proteins similarly to other ROS by affecting sulfur-containing (Met and Cys) and aromatic (Trp, Tyr, Phe, and His) residues although Phe and Cys are much less reactive. Studies with ambient air ozone $[14,15]$ and aqueous ozone [16-19] have agreed on the following relative reactivity: Met $>\operatorname{Trp}>\operatorname{Tyr}>$ His $>$ Phe $>$ Cys.

Performic acid oxidizes Met, Tyr, and Trp, leading to sulfoxide formation and aromatic hydroxylation, respectively. It is used specifically for oxidative cleavage of disulfide bonds, producing two cysteic acid residues [20,21]. Sulfenic acid is an unstable intermediate oxidation product of Cys (Fig. 1). It may be further oxidized to unreactive sulfinic acid and sulfonic acid (cysteic acid). Sulfenic acid reacts readily with nucleophiles, including other Cys residues, with which it can form a disulfide bond [22].

ROS are highly reactive and can modify most amino acid residues. As shown later in this review, such nonspecific modifications are useful for protein surface mapping experiments. They are, however, of limited utility for selective, oxidative modifications.

\section{Reactive nitrogen species}

RNS mainly derived from nitric oxide $\left(\mathrm{NO}^{\bullet}\right)$ lead to nitration and nitrosation of proteins in vivo [2]. RNS, in comparison with ROS, preferentially oxidize sulfurcontaining (Cys and Met) and aromatic (Tyr, Trp, Phe, and His) amino acids. In vivo nitration of Tyr is a well known widely studied phenomenon, whereas nitration of Trp has received less attention [23]. Tyr nitration occurs at the ortho positions and dinitration is possible [24].

Peroxynitrite $\left(\mathrm{ONOO}^{-}\right)$, which may be formed from $\mathrm{NO}^{\bullet}$ and superoxide anion $\left(\mathrm{O}_{2}{ }^{-\bullet}\right)$, is thought to be the primary agent for reaction with Cys, Met, and Trp, whereas for reaction with Tyr, Phe, and His secondarily formed radicals are thought to be involved [24]. Reaction with $\mathrm{NO}_{2}$ is believed to be the main in vivo Tyr nitration pathway [25-27].

Reaction of Cys with NO in the presence of oxygen may lead to nitrosation of the thiol group [28]. In addition, formation of sulfenic acid is possible with RNS in a similar way as with ROS [24].

RNS are more selective than ROS and thus potentially more suitable for site-directed labeling of peptides and proteins. Subsequent reduction of nitrated Tyr or Trp to the corresponding aromatic amines is a useful approach for site-directed labeling [29, 30].

\section{Reactive halogen species}

Reactive halogen species are oxidized forms of chlorine, bromine, and iodine, including hypohalous acids, which readily react with aromatic amino acids. The oxidized halogen intermediate may be formed through reaction between halide anions and oxidizers, such as $\mathrm{H}_{2} \mathrm{O}_{2}$ (see "Chemical methods"). Reaction with Cys and Met to form sulfoxides is possible (Fig. 1) [22, 31] and cystine can yield $N$ dichlorocystine, but halogenation of free Cys is not observed. The extent of oxidation of Cys, Met, and His can be limited by using substoichiometric amounts of oxidizing agents.

Reaction with Tyr and Trp leads to single or multiple halogenations (see below). Halogenated intermediates (Fig. 2) react with other nucleophiles, including water, leading to hydroxylation or cleavage of adjacent peptide bonds. Oxidative halogenation and cleavage of peptide bonds C-terminal to Tyr and Trp often occur simultaneously 
a
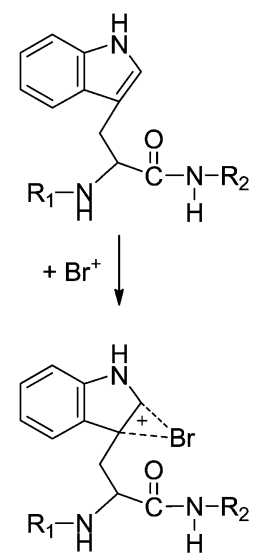

(2)<smiles>[R]NC1CC2(OC1=O)C(=O)Nc1cc(Br)ccc12</smiles>

$+\mathrm{H}_{2} \mathrm{O} \downarrow-\mathrm{HBr}, \mathrm{H}^{+}$

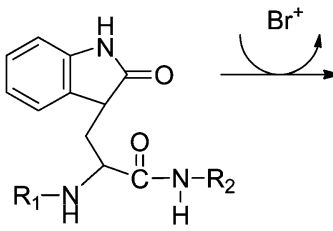

(1)

b
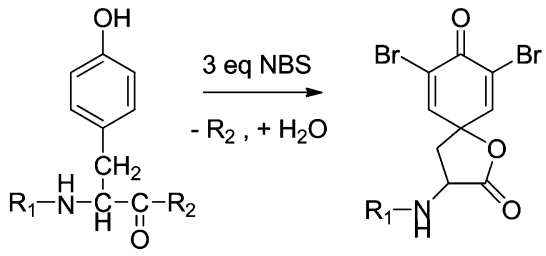

Fig. 2 a Proposed reaction pathway for oxidation reaction of Trp with bromine [39]. A first oxidation step with $\mathrm{Br}^{+}$leads to the oxoindole (1), followed by a second oxidation, which induces internal cleavage of the peptide bond (2). In the presence of an excess of bromine, halogenation of the six-membered ring occurs (3). b The analogous reaction of Tyr with 3 equiv of $N$-bromosuccinimide $(N B S)$ leads to a dibrominated, cleaved Tyr residue [138]

and can be achieved by chemical or electrochemical methods (see "Direct electrochemical oxidation of peptides and proteins"). Some selectivity for the cleavage reaction is observed, depending on the size of the reactant and the redox activity of Tyr or Trp (at low $\mathrm{pH}$ the redox potential of Trp is slightly lower than that of Tyr [32]). $N$-Bromosuccinimide, $N$-iodosuccinimide, and $N$-chlorosuccinimide have been used to cleave peptide bonds C-terminal to Tyr [33-35] and $\operatorname{Trp}[36,37]$ residues. In all cases cleavage is accompanied by halogenation. Reagents have been proposed that are selective for Trp (e.g., ortho-iodosobenzoic acid) but have never achieved widespread use [38].

Halogenation of Tyr is most favorable at the ortho position (Figs. 1, 2b), yielding a mixture of singly and doubly halogenated Tyr. For Trp the 2 position of the pyrrole ring and any position on the six-membered aromatic ring are targeted [39], analogous to naturally occurring Trp bromina- tion patterns [40] (Figs. 1, 2a). Oxidation by reactive halogen species usually leads first to 2-oxoindole formation (Fig. 2a, structure 1) through reaction with water. Subsequent oxidation reactions result in halogenation of the six-membered aromatic ring, presumably at the 5-position, and/or peptide bond cleavage, as illustrated in Fig. 2a [39]. The secondary oxidation of the 2-oxoindole leads to an intramolecular reaction to form an iminolactone, which is readily hydrolyzed, cleaving the tryptophanyl or tyrosyl peptide bond (Fig. 2a, structure 2). The reaction of Trp with 3 equiv of $N$ bromosuccinimide leads to monobrominated, cleaved 2-oxoTrp [41], whereas the equivalent reaction with Tyr produces a dibrominated, cleaved Tyr residue [39] (Fig. 2b).

Hypohalous acids, such as $\mathrm{HOCl}$ and $\mathrm{HOBr}$, produce mainly halogenated Tyr and Trp, as well as 2-oxo-Trp [4244]. In addition, many other minor modifications of these and other residues have been described [45]. Mono- and dichlorination of Tyr with performic acid in the presence of $\mathrm{Cl}^{-}$have been observed, which may be ascribed to intermediate $\mathrm{HOCl}$ formation $[46,47]$.

\section{Production and use of oxidizing agents}

\section{Chemical methods}

Chemical oxidants can be added directly to a protein sample or generated after chemical, photochemical, electrochemical, or enzymatic activation (see below). Hydrogen peroxide is the most easily obtained oxidizing agent. Hydroxyl radicals are formed from hydrogen peroxide or from water by chemical, electrochemical, or photochemical activation. Online reactions coupled with electrospray-MS or reactions on the target plate for matrix-assisted laser desorption/ionization (MALDI)-MS [48] have the advantage that sample handling is avoided.

Various peroxide species are produced by combining hydrogen peroxide and precursors, such as nitrite to form peroxynitrite [49], or formic acid to form performic acid [47]. Reactive halogen species include hypohalous acids such as $\mathrm{HOCl}$ and $N$-halogensuccinimides. Others are produced by oxidizers such as hydrogen peroxide to form hypohalous acids with molecular halogens $\left(\mathrm{I}_{2}\right.$ and $\left.\mathrm{Br}_{2}\right)$ or alkali halides. Iodination of Tyr is used in radiology, where radioactive iodine $\left({ }^{125} \mathrm{I}\right)$ is incorporated in proteins, typically with ${ }^{125} \mathrm{I}^{-}$which is activated by chloramine $\mathrm{T}$ [50].

Metal-catalyzed oxidation of proteins with transition metal complexes (e.g., ruthenium bipyridine or porphyrinlike compounds) is used for photochemically or chemically induced oxidation of Trp, Tyr, and Cys to their radical intermediates [51, 52]. Such methods are most commonly employed for protein cross-linking or to determine the metal-binding site of proteins $[53,54]$. 
The Fenton reaction has been used to produce hydroxyl radicals from hydrogen peroxide by addition of Fe(II) for Trp and Tyr oxidation and cross-linking studies $[55,56]$. An iron complex has been constructed which produces oxoferryl $[\mathrm{Fe}(\mathrm{IV})=\mathrm{O}]$ in combination with hydrogen peroxide [57], which is claimed to be potentially more specific than other ROS such as hydroxyl radical owing to lower diffusion.

Reactive intermediates produced by irradiation

Hydroxyl radicals are photochemically generated either by photolysis of hydrogen peroxide or by radiolysis of water. Photolysis induced by a UV lamp [58] or a laser [59-65] and radiolysis induced by X-ray [66-70] and $\gamma$-ray [71] irradiation as well as pulsed electron beam methods [72] have proven to be useful to produce hydroxyl radicals for protein footprinting experiments (see "Protein surface mapping").

Photochemical oxidation of hydroquinone with a UV laser on a MALDI target coated with $\mathrm{TiO}_{2}$ particles has been shown to produce benzoquinone, which reacts with thiols in peptides [73]. This parallels the electrochemical generation of benzoquinone in the electrospray emitter reported by the same group (see "Electrospray emitter"). Furthermore, metal complexes employed in protein oxidation can be photochemically activated, e.g., the rutheniumbipyridine complex [52].

\section{Electrochemically produced reactive intermediates}

Electrochemistry is a useful method of producing ROS in a controlled manner. An electrochemical cell can be used to oxidize water to hydroxyl radicals at sufficiently high potential. Boron-doped diamond (BDD) electrodes are particularly suitable for hydroxyl radical production owing to their intrinsic high overpotential for the formation of molecular oxygen by oxidation of water (oxygen evolution) $[74,75]$. The potential at which the radical formation is observed is dependent on the doping and impurity level of the BDD material employed [75]. Another major advantage of $\mathrm{BDD}$ when it comes to protein analysis is its low adsorption. Adsorption of proteins and peptides to the working electrode affects the reproducibility, as has been observed when working with commonly used carbon electrodes [76]. Hydroxyl radical formation at high voltage combined with the low adsorption properties makes BDD a suitable and efficient material for footprinting experiments [77] (see "Protein surface mapping").

The Fenton reaction (see "Chemical methods") can be initiated in an electrochemical cell [78]. Alternatively, the electrospray emitter of a mass spectrometer's source can be employed to oxidize atmospheric oxygen. High voltage on the electrospray emitter tip (typically above $5 \mathrm{kV}$ ) can generate a corona discharge, which leads to hydroxyl and perhydroxyl radical formation and subsequent peptide oxidation in the gas phase [79], an approach that has been used for protein footprinting experiments [80, 81] (see "Protein surface mapping"). However, Boys et al. [82] showed recently that corona discharge can occur under regular electrospray ionization (ESI) conditions $\left(3.5 \mathrm{kV}, \mathrm{N}_{2}\right.$ nebulizer gas) and induce hemoglobin oxidation. Electrochemical production of RNS in an electrochemical cell has been shown to lead to Tyr nitration $[83,84]$ by oxidation of nitrite to nitrogen dioxide or peroxynitrite.

\section{Enzymatically produced reactive intermediates}

Peroxidases are often used for production of ROS or RNS in in vivo assays. Both the enzyme and an oxidizing reagent may be added to a protein sample, but more commonly peroxidases are supplied with hydrogen peroxide to induce in situ oxidation. For example, myeloperoxidases can produce $\mathrm{HOCl}$ from $\mathrm{Cl}^{-}$and $\mathrm{H}_{2} \mathrm{O}_{2}$, and $\mathrm{NO}_{2}$ from nitrite and $\mathrm{H}_{2} \mathrm{O}_{2}$ [85], leading to Tyr chlorination and nitration, respectively.

The tyramine labeling system [86] uses peroxidase activity to cross-link tyramine to Tyr residues in proteins. Tyramine-fluorophore labeling has been used to probe Tyr radical formation in vivo [87].

\section{Direct electrochemical oxidation of peptides and proteins}

\section{Electrochemical cell}

Electrochemistry has long been a domain reserved to specialists but the coupling of electrochemistry with MS has generated increased interest owing to its ability to monitor electron transfer processes online. Many groups have contributed to the development of methods and instrumentation for coupling of electrochemical cells to MS and LC-MS systems (see [88-90] for reviews).

Electrodes can donate or accept electrons and thus reduce or oxidize macromolecules. Metalloproteins have, for instance, been widely studied because of their crucial role in in vivo redox processes [91]. The electrochemistry of biomacromolecules is mainly used for detection purposes and in that aspect metalloproteins are easily oxidizable targets owing to their metal ion cofactor.

Electrochemistry is also used to mimic oxidative modifications occurring in vivo through enzymatic and ROS activity. Indeed, proteins contain electroactive amino acid residues whose side chains can interact with an electrode and undergo electron transfer reactions. Sulfur-containing Cys and Met residues as well as the aromatic Tyr, Trp, and His are susceptible to direct oxidation reactions in an electrochemical 
cell when a positive potential is applied to the working electrode. Reduction of disulfide bridges can, on the other hand, be achieved by applying negative potentials [92].

Electrochemical oxidation of aromatic amino acids produces reactive intermediates which mainly yield hydroxylated residues by reaction with water and, for Tyr, quinones after secondary oxidation reactions. Sulfurcontaining residues can be oxidized through up to three oxygen atom insertions in the case of Cys [90]. Another common oxidation reaction for Cys is to form a disulfide bond with another Cys residue. Recent work in our group showed that cleavage of the protein backbone can occur after electrochemical oxidation of peptides and proteins [76, 93]. Similarly to the chemical cleavage with halogen species described in "Reactive halogen species," electrochemical oxidation of peptides and proteins leads to the preferred cleavage of peptide bonds C-terminal to Tyr and Trp residues. The cleavage reaction yields a spirolactone derivative of Tyr and Trp (Fig. 2). This amino acid specificity makes it a promising method for the development of an alternative protein digestion technique. Interestingly, it has been shown that the method can be used to distinguish phosphorylated Tyr from Tyr, since phosphoTyr cannot be oxidized and thus no cleavage occurs [93].

Proteins have not been extensively studied in terms of oxidative side-chain modifications using electrochemistry although it is a potentially useful method to mimic in vivo processes. Brabec and Mornstein [94, 95] first presented electrochemical oxidation of Tyr and Trp side chains in the protein backbone. Nitration of Tyr side chains in lysozyme has also been investigated by electrochemical oxidation of nitrite [84].

Carbon-based working electrodes are the most commonly used working electrodes in organic electrochemistry but have the main drawback of surface oxidation and fouling due to irreversible adsorption when working with large peptides and proteins. This strongly hampers accurate analysis and reproducibility. BDD electrodes have recently gained considerable attention owing to their chemical inertness, large potential window, and more importantly their lower adsorption properties as compared with glassy carbon $[74,75]$. Shin et al. [96] showed strongly reduced adsorption of bovine serum albumin to BDD electrodes as compared with glassy carbon and Chiku et al. investigated the direct electrochemical oxidation [97] and conformational changes of bovine serum albumin [98] using BDD electrodes, indicating that this electrode material is suitable for protein analysis.

\section{Electrospray emitter}

The simplest configuration to perform electrochemical oxidation in combination with MS is to make use of the inherent electrochemical processes occurring within the electrospray emitter of the mass spectrometer. Blades et al. [99] were the first to compare the ESI source to an electrolytic cell by showing that $\mathrm{Zn}(\mathrm{II})$ and $\mathrm{Fe}(\mathrm{II})$ ions were generated in solution by electrochemical oxidation of the emitter tip. ESI by its nature involves electrochemical processes. In positive ionization mode, positively charged droplets formed at the emitter tip flow towards the aperture of the mass spectrometer owing to the applied electrical field. The way to balance charges and to allow current to flow through the entire circuit is by providing electrons at the liquid-metal interface by electrochemical oxidation of the metallic emitter tip and/or electrolytes present in solution to release electrons, although there is ongoing discussion about this process $[100,101]$. The emitter can thus act as a working electrode where oxidation (positive ion mode) or reduction (negative ion mode) reactions take place, whereas the curtain plate or inlet capillary of the mass spectrometer plays the role of the counter electrode. Van Berkel and coworkers studied the fundamental aspects of the ESI process extensively [101] and "in source" redox reactions were mainly used to ionize compounds such as porphyrins [102], polyaromatic hydrocarbons [103], metallocenes [104], and fullerenes [105] in the form of radical cations in positive ion mode.

Girault and coworkers pioneered the use of in source redox reactions for peptide and protein analysis. In their work, hydroquinone was oxidized to benzoquinone, which reacts with the thiol groups of Cys in peptides and proteins within the emitter as shown in Fig. 3a [106-110]. In this way they developed a system for "online counting" of Cys residues with the goal to facilitate peptide identification through database searches, which is enhanced when at least one amino acid residue in the sequence is known [109, 111, 112]. The technique was shown to be successful on a set of peptides containing up to three Cys residues and on proteins, although the tagging efficiency decreased with increasing molecular size owing to steric hindrance and slower kinetics.

The same group explored the use of sacrificial electrodes on microchip devices to generate metal ions in solution $[\mathrm{Cu}$ (II), $\mathrm{Zn}(\mathrm{II}), \mathrm{Ni}(\mathrm{II}), \mathrm{Fe}(\mathrm{II})$, and $\mathrm{Ag}(\mathrm{I})]$ that can complex to peptides (Fig. 3b) [113]. The use of copper and zinc electrodes appeared to be most efficient to probe metal ionprotein interactions that mimic those observed in biological systems. Copper sacrificial electrodes, for instance, were used to study copper-Cys interactions [114-116]. Copper is known to catalyze Cys oxidation in vivo [117] and it was shown that generating $\mathrm{Cu}(\mathrm{I})$ and $\mathrm{Cu}(\mathrm{II})$ ions in solution promoted the formation of inter- or intramolecular disulfide bridging. Alternatively, a sacrificial zinc electrode was used to tag phosphopeptides. $\mathrm{Zn}$ (II) ions generated at the emitter tip were shown to interact with phosphopeptides and complex phosphorylated Tyr and Ser $[116,118]$. 


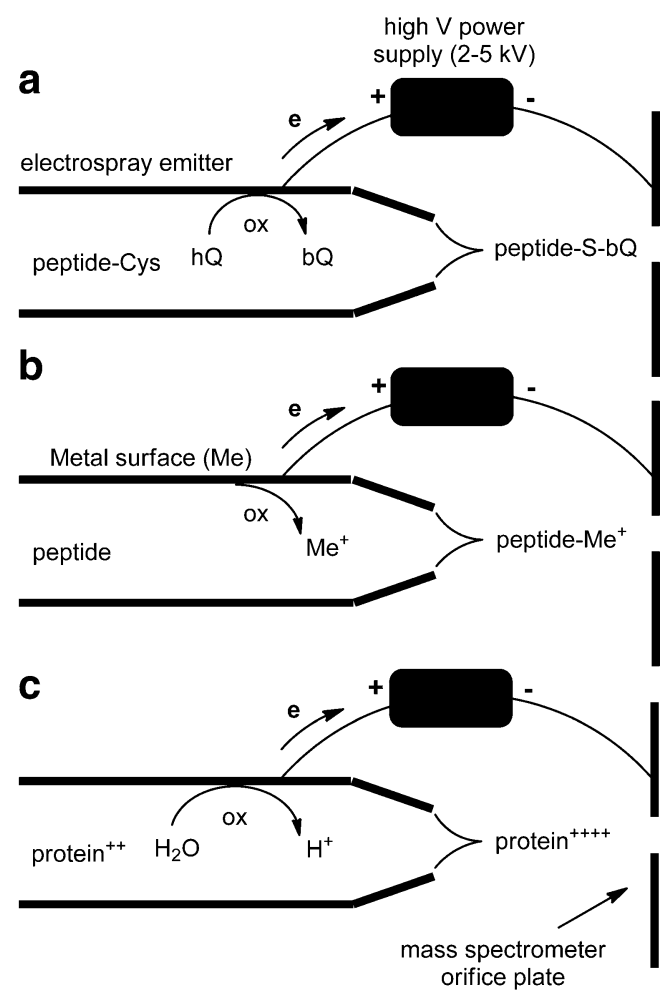

Fig. 3 Oxidation reactions in an electrospray emitter. a Oxidation of hydroquinone $(h Q)$ to benzoquinone $(b Q)$ in the presence of Cyscontaining peptides leads to quinone-labeled peptides [106]. b Oxidation of metals (e.g., from the emitter material itself) leads to metal ions that may coordinate with peptides [113]. c Oxidation of water reduces the solvent $\mathrm{pH}$, leading to higher protein charge states [121]

Redox reactions taking place at the electrospray emitter electrode can affect the composition of the solution in the capillary $[119,120]$. Oxidation or reduction of water at the liquid-metal interface (Fig. 3c) can induce a variation of the $\mathrm{pH}$ in solution. Pan et al. [121] showed that this change of solution composition can be used to enhance ubiquitin, myoglobin, and cytochrome $c$ detection in negative ion mode. Indeed reduction of water within the electrospray capillary progressively increased the basicity of the solution, through formation of $\mathrm{OH}^{-}$ions, thus altering the charge state of the different proteins and improving the detection in negative ESI-MS. The electrochemical modification of a solute inside the electrospray capillary is strongly dependent on the liquid flow rate. When the flow rate is increased, there is a lower yield of electrochemical reaction products [101].

\section{Applications}

Applications of chemical modifications and tagging strategies for protein research and proteomics have been covered in recent reviews [122-124]. Here we highlight applications where oxidation facilitates sample preparation and purifi- cation, and those where oxidative changes of the physicochemical properties with respect to chromatographic separation, ionization efficiency, or mass are utilized for improved or differential detection of labeled peptides.

\section{Sample preparation}

Oxidative modification for sample preparation is most commonly performed at the protein level. The oxidized functional group may be the end point of labeling, but oxidation methods can also be employed for the creation of functional groups for secondary labeling, e.g., biotinylation for affinity purification or fluorescent labeling for detection.

a

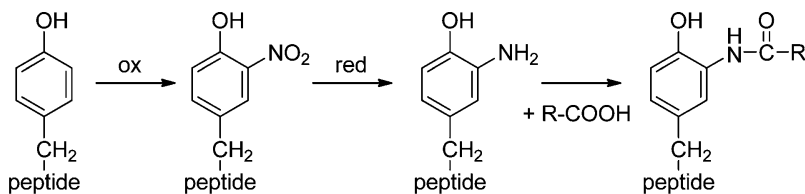

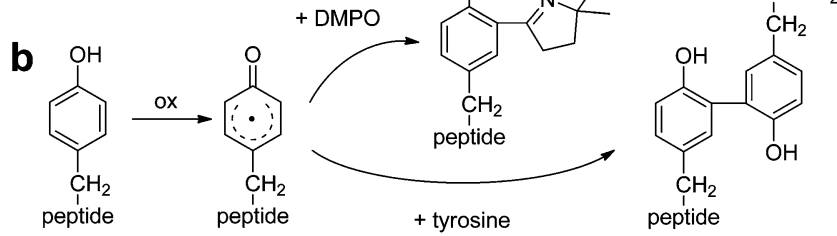

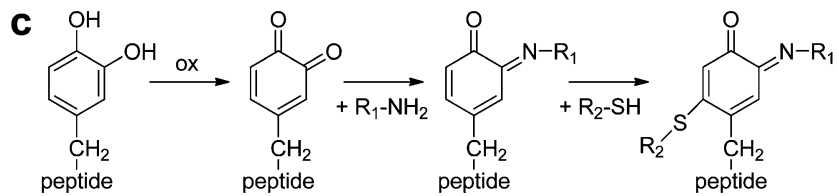

d
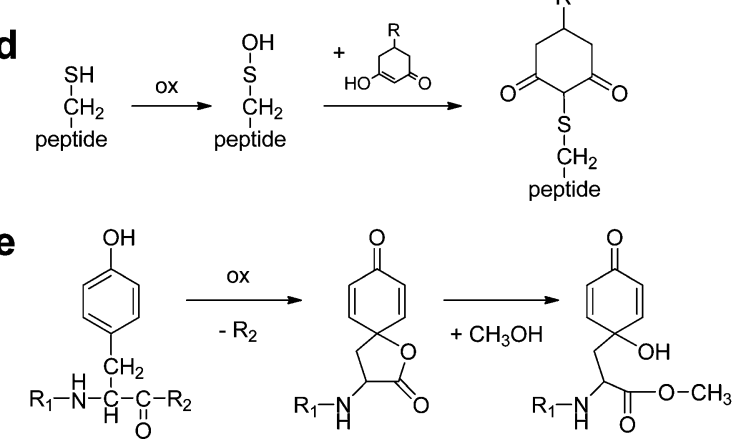

Fig. 4 Secondary labeling reactions of oxidized amino acid residues. a Oxidative nitration, followed by reduction of the nitro group to an amine, and finally amide formation $[27,131]$. b Reaction of the radical intermediate of Tyr with the spin-label 5,5-dimethylpyrroline- $N$-oxide $(D M P O)$ [134] or a second Tyr residue [51]. c Secondary oxidation of hydroxylated Tyr to an orthoquinone, followed by reaction with an amine (e.g., a protein Lys), leading to a Schiff base intermediate, which is very reactive towards thiols [51]. d Reaction of sulfenic acid with a linker molecule containing secondary amine or azide functional groups for labeling [137]. e Tyr peptide bond cleavage leads to a lactone intermediate that can react with alcohols or amines [138] 
Figure 4 illustrates a variety of secondary labeling methods after oxidation of amino acids. Nitro-Tyr can be reduced with sodium disulfite [125], dithiothreitol in combination with heme [126], or by electrochemical reduction [127-130] and yield amino-Tyr. This amine group is useful for coupling labels (Fig. 4a) such as biotin [27, 30, 131], sulfhydryl groups [29], or fluorescent tags [132]. This strategy allows isolation of residues containing the modified amino acids. Zhang et al. [29] and Abello et al. [30] showed selective tagging of nitro-Tyr after prior acetylation of primary amines.

Oxidative cross-linking of radical intermediates of Tyr with other Tyr residues (Fig. 4b) or with tyramine coupled to a fluorophore [51, 52, 87] produces dityrosine-containing compounds with distinct spectroscopic properties. Crosslinking reactions are of great interest owing to the fact that they involve residues (Tyr, Trp, Cys) that often play an essential role in protein function and biological recognition processes. Studies of such reactions have, for instance, revealed intermolecular interactions between G-proteincoupled receptors within intact cells [51] or that neutrophilderived proteins with anti-inflammatory and bactericidal properties are more susceptible to attack by Tyr radicals [87]. The biological role of protein Tyr radicals can be assessed by trapping them with the spin-label 5,5-dimethylpyrroline- $N$ oxide before they react with other radicals (Fig. 4b). The trapped radicals are stable enough for subsequent tryptic digestion and MS analysis and can thus be localized in the protein $[133,134]$. Such studies allow one to map the radicals in proteins under oxidative stress, leading to a better understanding of the mechanisms that are related to human diseases. Trapped Tyr residues can also be detected with antibodies and by molecular magnetic resonance imaging [135].

Tyr orthoquinone is produced by a second oxidation after oxidative hydroxylation (see "Electrochemical cell"). This group is susceptible to nucleophilic attack by thiols, as shown in Fig. 4c, or by other oxidized Tyr residues [51, 136]. Sulfenic acid is capable of nucleophilic attack, which has been used to couple a linker molecule that subsequently reacts with fluorescent labels [137] (Fig. 4d).

The spirolactone group of Tyr, which is produced upon peptide cleavage, is reactive towards alcohols and amines under basic conditions to form esters and amides (Fig. 4e) [138]. An analogous reaction with amines such as tris(hydroxymethyl) aminomethane has been described for the homoserine lactone produced by $\mathrm{CNBr}$ cleavage C-terminal to Met [139].

Protein digestion for proteomics, which is typically performed enzymatically, may be achieved by electrochemical or chemical oxidative cleavage of proteins as described in "Reactive halogen species" and "Electrochemical cell." The distinct specificity and the reactive spirolactones of Tyr and $\operatorname{Trp}$ at the peptide C-terminus may provide novel peptide enrichment and identification strategies.

\section{LC properties}

Oxidative labeling may change peptide retention on the chromatographic stationary phases. Hydroxylation of Tyr and Trp and oxidation of Met and Cys to sulfoxide or sulfoacids decrease their hydrophobicity, thus reducing peptide retention on reversed phase (RP) columns. Hydrophobicity and elution order may be further affected by solvent composition and $\mathrm{pH}$ (e.g., nitro-Tyr has a longer retention time than Tyr in RP-HPLC under acidic conditions, but is eluted earlier under basic conditions [27]). Increased retention times are observed upon halogenation, so Tyr, bromo-Tyr, and dibromo-Tyr are eluted in this order in RP-HPLC [140].

Direct comparison of labeled versus unlabeled samples is possible, but as for peptide mass shifts (see "Mass change of peptides and fragments"), sample complexity and low abundance of peptides of interest can make retention time shifts hard to detect. To overcome this issue the COFRADIC method has been developed [3], which is a two-stage LC method with a primary separation, labeling of certain molecules or functional groups in fractions, and a secondary separation. Differential labeling will cause a shift in retention time for labeled peptides, whereas unlabeled peptides remain unaffected, making labeled peptides easily detectable. COFRADIC has been applied to various targets based on different labeling methods, including oxidation of Met with performic acid [141]. Met oxidation has also been used to reduce the hydrophobicity of peptides derived from membrane proteins, which are difficult to elute from RP stationary phases [142]. This is a case where oxidative modification of Met residues, which are often located in transmembrane segments, leads to increased peptide coverage, which is often an issue when analyzing membrane proteins by LC-MS. Reaction of Cys with benzoquinone, similar to the electrospray tagging reaction (see "Electrospray emitter"), has been employed to induce a hydrophilic shift in COFRADIC with RP-HPLC [143].

\section{Mass-spectrometric properties}

Ionization efficiency and charge state

Protein solution-phase conformation influences the charge state of a protein during the ESI process [144, 145]. The charge state itself influences the ionization efficiency of proteins since highly charged conformers are more easily amenable to ESI. A protein in its native folded conformation gives rise to lower-charge states (fewer available protonation sites) and a wider charge distribution compared with its unfolded equivalent. On the basis of this empirical relationship, ESI-MS has been used as a tool for monitoring 
protein conformational changes in solution [146], including for protein footprinting experiments [147] (see "Protein surface mapping"), where oxidative modifications affect the solution-phase structure. The nature of the oxidized residue can also affect the charge state as testified, for instance, by the lower proton affinity of 2-oxo-His compared with unmodified His [148]. Oxidation of Cys to cysteic acid can, on the other hand, contribute to an increase of the charge state in negative ion mode owing to its acidity. It is also noteworthy that the peptide dissociation patterns in MS/MS may be affected by oxidatively modified residues, which must be taken into account during the interpretation of MS/MS spectra [148] (see "Mass change of peptides and fragments"). Ionization efficiency can also be increased by taking advantage of inherent electrochemical processes taking place in the electrospray emitter as discussed in "Electrospray emitter."

Mass change of peptides and fragments

Almost any labeling method, including oxidation, will increase the mass of an analyte. Differential MS analysis of oxidized versus unoxidized samples will therefore reveal modified peptides, provided that they are sufficiently abundant and can be ionized well. Alternatively, much more sensitive MS/MS methods can selectively detect modified peptides on the basis of characteristic product ions or neutral losses [149]. Table 1 lists precursor and neutral loss scanning applications that have been described for various (in vivo) modifications that can be mimicked by oxidative labeling.

Collision-induced dissociation of peptides is influenced by the side-chain properties of the constituent amino acids. Notably, creation of acidic or basic groups affects the proton localization, so formation of sulfinic acid and sulfonic acid leads to greatly increased fragmentation at their C-terminal side [150], analogous to the preferential fragmentation induced by aspartic acid [151]. This observation may help in interpreting MS/MS spectra of unknown peptides [152]. In contrast, the preferential fragmentation normally observed for His is inhibited upon its oxidation to 2-oxo-His [148].

Although fragmentation of protonated peptides by collision-induced dissociation is the most common technique in proteomics, electron-transfer-induced dissociation has gained considerable interest since its introduction in 2004 [153], and applications targeting oxidized residues are easily envisaged. In a related method, iodinated Tyr is irradiated in the gas phase to produce radical intermediates which readily fragment upon collisional activation [154].

Mass defect and isotopic pattern signature

In addition to the overall mass increase upon labeling, the elemental composition of the labeling group may introduce a shift in the mass defect of the peptide or protein, which is on average $+0.00055 \mathrm{amu}$ per amu for protein-derived peptides. Labels with many hydrogen atoms cause an additional positive mass defect, whereas incorporation of heavier elements, including chlorine, bromine, and iodine, leads to an increasingly large negative mass defect (Table 2). The term "mass-deficient mass tag" (MaDMaT) was proposed by Steen and Mann [155]. The large mass defect of halogens may be used for the preparation of internal standards for quantitative proteomics [156]. MaDMaTlabeled peptides are easily distinguished from nonlabeled peptides in a mass spectrometer with sufficient mass resolution and accuracy [156]. Performic acid oxidation of Met [20] or halogen labeling [157, 158] expands the mass distribution of tryptic peptides, and the compositional information may be used to improve peptide identification.

The well-known specific isotope patterns of chlorine and bromine are used to confirm their presence and number from the relative isotope intensities (Table 2). In combination with
Table 1 Specific fragments of oxidatively modified amino acid residues used for tandem mass spectrometry based detection

\begin{tabular}{|c|c|c|c|c|}
\hline Residue & Modification & Precursor immonium ion $(\mathrm{Da})$ & Neutral loss (Da) & References \\
\hline \multirow[t]{2}{*}{$\operatorname{Trp}$} & Bromo & $\begin{array}{l}237.002 \\
239.001^{\mathrm{a}}\end{array}$ & & {$[155]$} \\
\hline & Hydroxy & 175.086 & & {$[45]$} \\
\hline \multirow[t]{5}{*}{ Tyr } & Hydroxy & 152.071 & & {$[45]$} \\
\hline & Bromo & 213.986 & & {$[174]$} \\
\hline & Chloro & 170.037 & & {$[45,174]$} \\
\hline & $\begin{array}{l}\text { Nitro } \\
\text { Dinitro }\end{array}$ & $\begin{array}{l}181.061 \\
226.046\end{array}$ & & {$[175]$} \\
\hline & $\begin{array}{l}\text { Iodo } \\
\text { Diiodo }\end{array}$ & $\begin{array}{l}261.973 \\
387.869\end{array}$ & & [176] \\
\hline Met & Sulfoxide & & 63.998 & {$[177,178]$} \\
\hline \multirow[t]{2}{*}{ Cys } & Sulfinic acid & & $65.977^{\mathrm{b}}$ & {$[150]$} \\
\hline & $\begin{array}{l}\text { Cam sulfoxide } \\
\text { Cam sulfone }\end{array}$ & & $\begin{array}{l}107.004 \\
122.999\end{array}$ & {$[179,180]$} \\
\hline
\end{tabular}

cam carbamidomethylcysteine produced by alkylation with iodoacetamide

${ }^{81} \mathrm{Br}$ isotope

${ }^{\mathrm{b}}$ Negative ionization 
Table 2 Effect of oxidative modifications of Tyr on the mass defect and isotope pattern of angiotensin I (DRVYIHPFHL). The average and lowest monoisotopic masses of tryptic peptides (without missed cleavages) were calculated in 1-Da mass bins from a yeast protein database (http://www.yeastgenome.org; orf trans.fasta database of 8 May 2009)

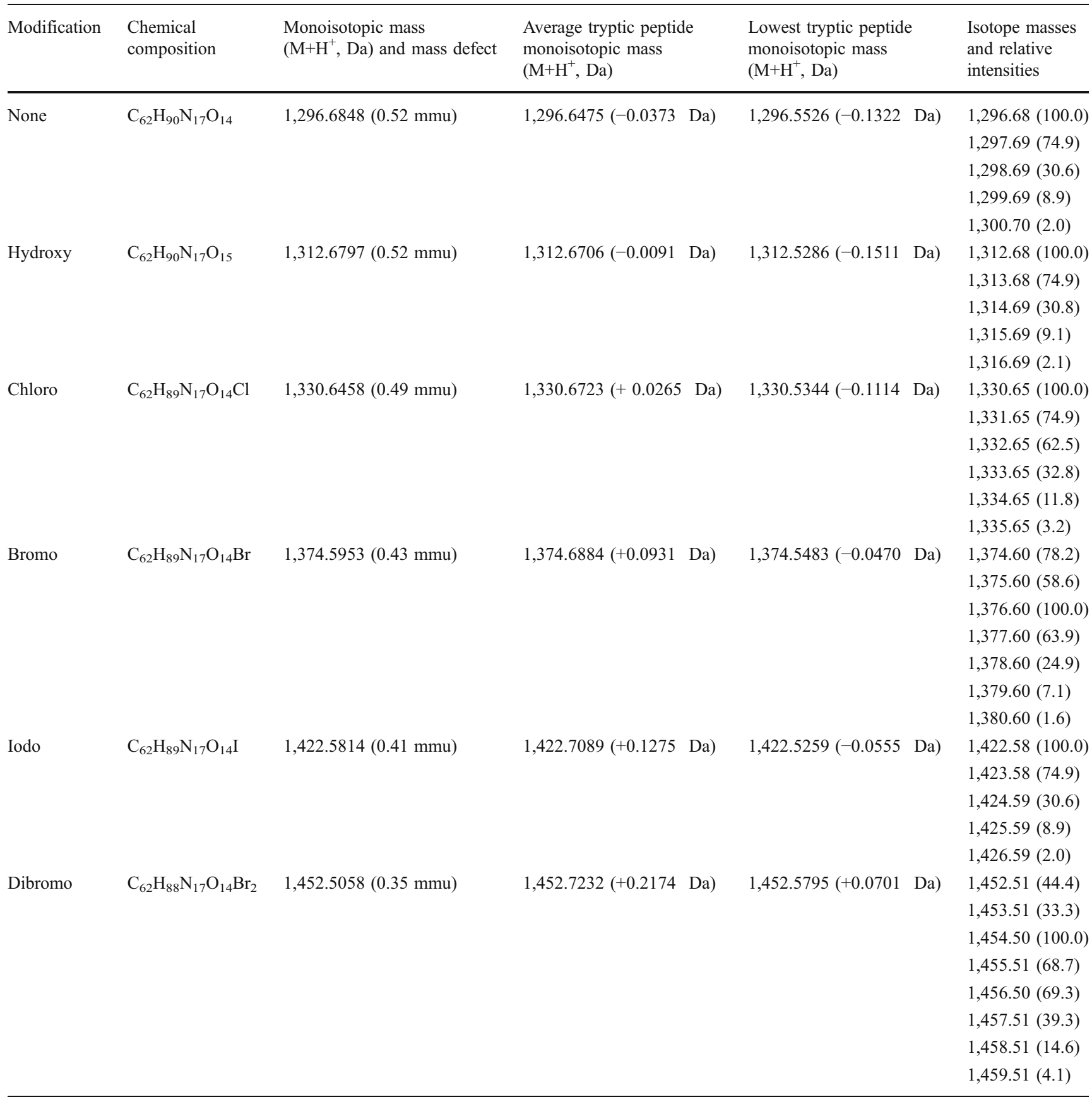

its large mass defect, the characteristic isotope pattern makes detection of labeled peptides in mass spectra rather straightforward.

\section{Differential isotopic labeling for quantitation}

Isotopic labeling is a standard approach in massspectrometric quantitation, and becoming increasingly important in proteomics. Synthesis of labeled peptides as well as metabolic and enzymatic labeling are widely used, but the most common method is chemical labeling either at the peptide or at the protein level. The primary labeling targets are the same as for nonisotopic labeling, such as primary amines of Lys residues or protein/peptide $\mathrm{N}$ termini [159, 160] or the thiol of Cys [161]. Labeling is performed by reaction with alkyl halide (nucleophilic substitution) or maleimide (thiols), or $N$-hydroxysuccini- 


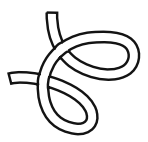

Protein

\section{Hydroxyl Radical Formation}

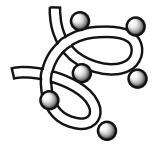

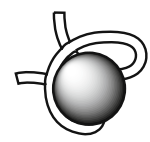

Protein + ligand

Oxidative Covalent Modification

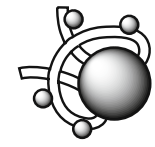

Generation of Unique Peptide Fragments Specific Protease

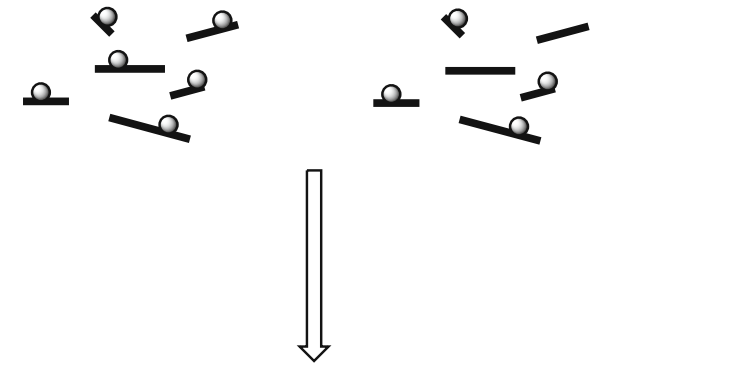

\section{MS Analysis \\ Extent of Modification}

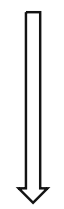

\section{MS/MS Analysis Identification of Oxidation Sites}

Fig. 5 Workflow for hydroxyl radical footprinting of proteins and protein/ligand complexes. $M S$ mass spectrometry. (Adapted from Xu and Chance [4])

midyl esters (amines). Trp is also a target for direct electrophilic aromatic substitution using the sulfenylation reagent 2-nitrobenzenesulfenyl chloride [162].

Oxidative labeling for quantitation is limited by the lack of specificity and completeness of the reactions, but it is certainly useful if incomplete labeling is acceptable. Other applications described to date comprise oxidative tagging with $\mathrm{H}_{2}{ }^{18} \mathrm{O}$ during ESI [163] and metabolic isotopic labeling of amino acid targets followed by $\mathrm{H}_{2} \mathrm{O}_{2}$ oxidation, as shown for Met in the COFRADIC workflow [164].

\section{Protein surface mapping}

Protein footprinting is a technique that gained attention during the last decade owing to its ability to probe solventaccessible residues. The technique of choice makes use of in situ generated hydroxyl radicals that induce oxidative chemical modification of surface-accessible reactive amino acid side chains. The term "footprinting" was introduced some 30 years ago by Galas and Schmitz [165], who performed DNA surface mapping. H/D exchange experiments are also used to probe surface-accessible residues by MS, but the need to quench the reaction at low $\mathrm{pH}$ to avoid back-exchange reactions during protein analysis limits their usefulness, since only a few proteases (e.g., pepsin) work under low $\mathrm{pH}$ conditions (see $[147,166]$ for reviews). We will focus here on the use of hydroxyl radicals that allowed considerable improvement in terms of spatial resolution compared with the bulky proteases used in other methods [167-169]. In addition, the fact that the small hydroxyl radicals nonspecifically attack a wide range of residues makes them better suited to probe solvent accessibility and thus a protein's tertiary and quaternary structure. Sulfurcontaining (Cys, Met, and cystine) and aromatic (Trp, Tyr, and $\mathrm{Phe}$ ) residues represent the most reactive targets for oxidative covalent modification, but other side chains (His, Leu, Ile, Arg, Lys, Val, Pro, Gln, and Glu) have also been shown to be modified [66-68, 70, 77, 170, 171]. Details about the chemical reactions underlying the covalent modification of amino acid side chains and backbone cleavage can be found in a detailed review by $\mathrm{Xu}$ and Chance [4].

The general footprinting workflow (Fig. 5) consists in producing hydroxyl radicals, which can be achieved by several means (see below and "Production and use of oxidizing agents") and different exposure times. After exposure, proteins are digested with proteases and the extent of oxidation is measured by MS. The location of oxidized amino acids is finally assigned by MS/MS analysis. The results obtained provide information about the solvent-exposed residues on the surface of the protein and can also lead to the determination of protein-ligand interaction sites by comparison of protein and proteinligand complexes. When protein oxidation is measured as a function of the time of exposure to the hydroxyl radicals, conformational changes can be followed owing to increased amino acid accessibility by protein unfolding induced by primary oxidation events.

A wide set of techniques to produce hydroxyl radicals have expanded the toolbox available for footprinting experiments (see "Production and use of oxidizing agents"). The Fenton reaction to produce hydroxyl radicals chemically $[55,56]$ has the main drawback that iron and EDTA may distort the native protein conformation. Photochemical 
formation of hydroxyl radicals by photolysis of hydrogen peroxide or by radiolysis of water is very efficient and provides the advantage (compared with the Fenton reaction) of fast (nano- to microseconds) radical generation, and the possibility of short exposure times (fewer oxidationinduced structural changes) allowing time-resolved studies. Radiolysis has the advantage of not requiring the addition of any reagent to the sample solution. Electrochemistry may also be used to generate reactive oxidants for the mapping of solvent accessibility. Whereas Brabec et al. [95, 172] have pioneered the use of electrochemical oxidation to probe protein conformational changes, new approaches for electrochemical-oxidation-based probing of the higherorder structure of proteins have been introduced by McClintock et al. [77] where hydroxyl radicals have been produced by oxidation of water on a BDD electrode. Oxidation in the electrospray source by corona discharge has also been performed [81, 173].

Protein footprinting experiments have found widespread application to probe protein structure and solvent-accessible residues in the native conformation. Moreover proteinprotein, protein-ligand, and protein-drug interaction sites as well as conformational changes (e.g., protein folding and unfolding) have been studied extensively, as shown by the many applications that have been reviewed in recent years $[4,68,80,147,171]$. Although footprinting methods have matured, some drawbacks such as secondary oxidation reactions are still an issue. It was observed that buried sulfur-containing residues can be oxidized either by internal electron transfer reactions [58] or by secondary oxidations due to residual hydrogen peroxide or peptidyl hydroperoxides [65]. Oxidation of non-solvent-accessible residues can hamper data interpretation and must be considered when performing footprinting experiments. Adding catalase and/or Met as scavengers limits secondary oxidations that may occur particularly on (buried) sulfur-containing residues [65] but internal electron transfer reactions are still difficult to avoid.

\section{Conclusion}

Oxidative labeling of peptides and proteins has expanded the toolbox of biochemists and notable progress has been made in the past decade. A variety of strategies for targeting amino acid side chains have been developed, in particular for sulfur-containing and aromatic residues. Current labeling techniques targeting primary amines (N-termini, Lys) and Cys residues have found widespread applications in proteomics, whereas other amino acids remain inaccessible to labeling to a large extend. The increased interest in oxidative labeling stems from the possibility to target other amino acid residues, such as Tyr, Trp, and Met, which have essential roles in protein function and biological recognition processes. Although the technique still suffers in many cases from incomplete conversion and selectivity, several applications in biological systems have shown its usefulness. It is, for instance, to be expected that oxidative labeling will help to improve our understanding of proteinprotein interactions with respect to protein function and signaling processes.

An interesting feature of oxidative labeling is its potential to introduce reactive groups in a site-specific manner, which can be targeted by secondary chemical reactions as shown for nitro-Tyr residues. Electrochemistry, which is far from being fully exploited, can efficiently induce such oxidative modifications. Many advances and developments have been observed in this field during the last decade and interesting applications can be envisaged especially owing to new developments in electrode materials and surface-modified electrodes. BDD electrodes, for example, are of interest owing to their reduced adsorption of biomolecules, opening the way for new applications of direct and ROS-mediated oxidation of peptides and proteins.

The increasing demand for MS-based proteomics methods and the relationship with in vivo oxidative protein damage through radical-induced modifications suggest that these techniques will find increasing use.

Acknowledgement This work was financially supported by the Dutch Technology Foundation (STW, grant 07047).

Open Access This article is distributed under the terms of the Creative Commons Attribution Noncommercial License which permits any noncommercial use, distribution, and reproduction in any medium, provided the original author(s) and source are credited.

\section{References}

1. Imlay JA (2003) Annu Rev Microbiol 57:395-418

2. Dalle-Donne I, Scaloni A, Giustarini D, Cavarra E, Tell G, Lungarella G, Colombo R, Rossi R, Milzani A (2005) Mass Spectrom Rev 24:55-99

3. Gevaert K, Van Damme P, Martens L, Vandekerckhove J (2005) Anal Biochem 345:18-29

4. Xu G, Chance MR (2007) Chem Rev 107:3514-3543

5. Bokoch GM, Knaus UG (2003) Trends Biochem Sci 28:502-508

6. Leto TL, Geiszt M (2006) Antioxid Redox Signal 8:1549-1561

7. Van der Vliet A (2008) Free Radic Biol Med 44:938-955

8. Garrison WM (1987) Chem Rev 87:381-398

9. Stadtman ER, Levine RL (2003) Amino Acids 25:207-218

10. Headlam HA, Davies MJ (2002) Free Radic Biol Med 32:11711184

11. Maskos Z, Rush JD, Koppenol WH (1992) Arch Biochem Biophys 296:521-529

12. Giulivi C, Traaseth NJ, Davies KJ (2003) Amino Acids 25:227232

13. Maskos Z, Rush JD, Koppenol WH (1992) Arch Biochem Biophys 296:514-520 
14. Cohen SL (2006) Anal Chem 78:4352-4362

15. Lloyd JA, Spraggins JM, Johnston MV, Laskin J (2006) J Am Soc Mass Spectrom 17:1289-1298

16. Verweij H, Christianse K, van Steveninck J (1982) Chemosphere 11:721-725

17. Berlett BS, Levine RL, Stadtman ER (1996) J Biol Chem 271:4177-4182

18. Kotiaho T, Eberlin MN, Vainiotalo P, Kostiainen R (2000) J Am Soc Mass Spectrom 11:526-535

19. Cataldo F (2003) Polym Degrad Stab 82:105-114

20. Matthiesen R, Bauw G, Welinder KG (2004) Anal Chem 76:6848-6852

21. Samgina TY, Artemenko KA, Gorshkov VA, Poljakov NB, Lebedev AT (2008) J Am Soc Mass Spectrom 19:479-487

22. Nagy P, Ashby MT (2007) J Am Chem Soc 129:14082-14091

23. Alvarez B, Rubbo H, Kirk M, Barnes S, Freeman BA, Radi R (1996) Chem Res Toxicol 9:390-396

24. Alvarez B, Radi R (2003) Amino Acids 25:295-311

25. Prutz WA, Monig H, Butler J, Land EJ (1985) Arch Biochem Biophys 243:125-134

26. Radi R (2004) Proc Natl Acad Sci USA 101:4003-4008

27. Abello N, Kerstjens HAM, Postma DS, Bischoff R (2009) J Proteome Res 8:3222-3238

28. Di Simplicio P, Franconi F, Frosali S, Di Giuseppe D (2003) Amino Acids 25:323-339

29. Zhang Q, Qian WJ, Knyushko TV, Clauss TRW, Purvine SO, Moore RJ, Sacksteder CA, Chin MH, Smith DJ, Camp DG, Bigelow DJ, Smith RD (2007) J Proteome Res 6:2257-2268

30. Abello N, Barroso B, Kerstjens HAM, Postma DS, Bischoff R (2010) Talanta 80:1503-1512

31. Shechter Y, Burstein Y, Patchornik A (1975) Biochemistry 14:4497-4503

32. Harriman A (1987) J Phys Chem 91:6102-6104

33. Schmir GL, Cohen LA, Witkop B (1959) J Am Chem Soc 81:2228-2233

34. Junek H, Kirk KL, Cohen LA (1969) Biochemistry 8:1844-1848

35. Alexander NM (1974) J Biol Chem 249:1946-1952

36. Patchornik A, Lawson WB, Witkop B (1958) J Am Chem Soc 80:4747-4748

37. Patchornik A, Lawson WB, Witkop B (1958) J Am Chem Soc 80:4748-4749

38. Mahoney WC, Hermodson MA (1979) Biochemistry 18:3810 3814

39. Burstein Y, Patchornik A (1972) Biochemistry 11:4641-4650

40. Bittner S, Scherzer R, Harlev E (2007) Amino Acids 33:19-42

41. Lawson WB, Patchornik A, Witkop B (1960) J Am Chem Soc 82:5918-5923

42. Pattison DI, Davies MJ (2001) Chem Res Toxicol 14:1453-1464

43. Pattison DI, Davies MJ (2004) Biochemistry 43:4799-4809

44. Fu X, Wang Y, Kao J, Irwin A, d'Avignon A, Mecham RP, Parks WC, Heinecke JW (2006) Biochemistry 45:3961-3971

45. Mouls L, Silajdzic E, Haroune N, Spickett CM, Pitt AR (2009) Proteomics 9:1617-1631

46. Chowdhury SK, Eshraghi J, Wolfe H, Forde D, Hlavac AG, Johnston D (1995) Anal Chem 67:390-398

47. Dai J, Zhang Y, Wang J, Li X, Lu Z, Cai Y, Qian X (2005) Rapid Commun Mass Spectrom 19:1130-1138

48. Corless S, Cramer R (2003) Rapid Commun Mass Spectrom 17:1212-1215

49. Robinson KM, Beckman JS (2005) Methods Enzymol 396:207214

50. Stein R, Goldenberg DM, Thorpe SR, Basu A, Mattes MJ (1995) Cancer Res 55:3132-3139

51. Kodadek T, Duroux-Richard I, Bonnafous J-C (2005) Trends Pharmacol Sci 26:210-217

52. Antos JM, Francis MB (2006) Curr Opin Chem Biol 10:253-262
53. Lim J, Vachet RW (2003) Anal Chem 75:1164-1172

54. Bridgewater JD, Vachet RW (2005) Anal Biochem 341:122-130

55. Dubinina EE, Gavrovskaya SV, Kuzmich EV, Leonova NV, Morozova MG, Kovrugina SV, Smirnova TA (2002) Biochemistry (Mosc) 67:343-350

56. Shcherbakova I, Mitra S, Beer RH, Brenowitz M (2006) Nucleic Acids Res 34:e48

57. Ekkati AR, Kodanko JJ (2007) J Am Chem Soc 129:1239012391

58. Sharp JS, Becker JM, Hettich RL (2004) Anal Chem 76:672683

59. Aye TT, Low TY, Sze SK (2005) Anal Chem 77:5814-5822

60. Charvátová O, Foley BL, Bern MW, Sharp JS, Orlando R, Woods RJ (2008) J Am Soc Mass Spectrom 19:1692-1705

61. Hambly DM, Gross ML (2005) J Am Soc Mass Spectrom 16:2057-2063

62. Pan Y, Brown L, Konermann L (2009) J Mol Biol 394:968-981

63. Pan Y, Stocks BB, Brown L, Konermann L (2009) Anal Chem $81: 28-35$

64. Stocks BB, Konermann L (2008) Anal Chem 81:20-27

65. Saladino J, Liu M, Live D, Sharp JS (2009) J Am Soc Mass Spectrom 20:1123-1126

66. Maleknia SD, Brenowitz M, Chance MR (1999) Anal Chem 71:3965-3973

67. Kiselar JG, Maleknia SD, Sullivan M, Downard KM, Chance MR (2002) Int J Radiat Biol 78:101-114

68. Guan J-Q, Chance MR (2005) Trends Biochem Sci 30:583-592

69. Xu G, Chance MR (2005) Anal Chem 77:4549-4555

70. Xu G, Kiselar J, He Q, Chance MR (2005) Anal Chem 77:30293037

71. Tong X, Wren JC, Konermann L (2008) Anal Chem 80:22222231

72. Watson C, Janik I, Zhuang T, Charvatova O, Woods RJ, Sharp JS (2009) Anal Chem 81:2496-2505

73. Qiao L, Roussel C, Wan JJ, Kong J, Yang PY, Girault HH, Liu BH (2008) Angew Chem Int Ed Engl 47:2646-2648

74. Kraft A (2007) Int J Electrochem Sci 2:355-385

75. Luong JHT, Male KB, Glennon JD (2009) Analyst 134:19651979

76. Permentier HP, Bruins AP (2004) J Am Soc Mass Spectrom 15:1707-1716

77. McClintock C, Kertesz V, Hettich RL (2008) Anal Chem 80:3304-3317

78. Jurva U, Wikström HV, Bruins AP (2002) Rapid Commun Mass Spectrom 16:1934-1940

79. Morand K, Talbo G, Mann M (1993) Rapid Commun Mass Spectrom 7:738-743

80. Maleknia SD, Downard K (2001) Mass Spectrom Rev 20:388401

81. Wong JWH, Maleknia SD, Downard KM (2005) J Am Soc Mass Spectrom 16:225-233

82. Boys BL, Kuprowski MC, Noël JJ, Konermann L (2009) Anal Chem 81:4027-4034

83. Kendall G, Cooper HJ, Heptinstall J, Derrick PJ, Walton DJ, Peterson IR (2001) Arch Biochem Biophys 392:169-179

84. Matters D, Cooper HJ, McDonnell L, Iniesta J, Heptinstall J, Derrick P, Walton D, Peterson I (2006) Anal Biochem 356:171181

85. Mohiuddin I, Chai H, Lin PH, Lumsden AB, Yao Q, Chen C (2006) J Surg Res 133:143-149

86. Larios JM, Budhiraja R, Fanburg BL, Thannickal VJ (2001) J Biol Chem 276:17437-17441

87. Avram D, Romijn EP, Pap EHW, Heck AJR, Wirtz KWA (2004) Proteomics 4:2397-2407

88. Volk KJ, Yost RA, Brajter-Toth A (1992) Anal Chem 64:21A$33 \mathrm{~A}$ 
89. Diehl G, Karst U (2002) Anal Bioanal Chem 373:390-398

90. Permentier HP, Bruins AP, Bischoff R (2008) Mini Rev Med Chem 8:46-56

91. Kaltashov IA, Zhang M, Eyles SJ, Abzalimov RR (2006) Anal Bioanal Chem 386:472-481

92. Rivat C, Fontaine M, Ropartz C, Caullet C (1973) Eur J Immunol 3:537-542

93. Permentier HP, Jurva U, Barroso B, Bruins AP (2003) Rapid Commun Mass Spectrom 17:1585-1592

94. Brabec V (1980) J Electroanal Chem 116:69-82

95. Brabec V, Mornstein V (1980) Biochim Biophys Acta 625:43-50

96. Shin D, Tryk DA, Fujishima A, Merkoçi A, Wang J (2005) Electroanalysis 17:305-311

97. Chiku M, Ivandini TA, Kamiya A, Fujishima A, Einaga Y (2008) J Electroanal Chem 612:201-207

98. Chiku M, Nakamura J, Fujishima A, Einaga Y (2008) Anal Chem 80:5783-5787

99. Blades AT, Ikonomou MG, Kebarle P (1991) Anal Chem 63:2109-2114

100. De La Mora JF, Van Berkel GJ, Enke CG, Cole RB, MartinezSanchez M, Fenn JB (2000) J Mass Spectrom 35:939-952

101. Van Berkel GJ, Kertesz V (2007) Anal Chem 79:5510-5520

102. Van Berkel GJ, McLuckey SA, Glish GL (1991) Anal Chem 63:1098-1109

103. Van Berkel GJ, Zhou F (1995) Anal Chem 67:3958-3964

104. Xu X, Nolan SP, Cole RB (1994) Anal Chem 66:119-125

105. Dupont A, Gisselbrecht J-P, Leize E, Wagner L, Van Dorsselaer A (1994) Tetrahedron Lett 35:6083-6086

106. Rohner TC, Rossier JS, Girault HH (2002) Electrochem Commun 4:695-700

107. Roussel C, Dayon L, Jensen H, Girault HH (2004) J Electroanal Chem 570:187-199

108. Roussel C, Dayon L, Lion N, Rohner TC, Josserand J, Rossier JS, Jensen H, Girault HH (2004) J Am Soc Mass Spectrom 15:1767-1779

109. Dayon L, Roussel C, Prudent M, Lion N, Girault HH (2005) Electrophoresis 26:238-247

110. Dayon L, Roussel C, Girault HH (2006) J Proteome Res 5:793-800

111. Hamdan M, Righetti PG (2002) Mass Spectrom Rev 21:287-302

112. Sechi S, Chait BT (1998) Anal Chem 70:5150-5158

113. Rohner TC, Girault HH (2005) Rapid Commun Mass Spectrom 19:1183-1190

114. Prudent M, Girault HH (2008) J Am Soc Mass Spectrom 19:560-568

115. Prudent M, Girault HH (2009) Metallomics 1:157-165

116. Prudent M, Méndez M, Roussel C, Su B, Lion N, Rossier J, $1 \mathrm{~S}$, Girault HH (2009) Chimia 63:283-287

117. Pecci L, Montefoschi G, Musci G, Cavallini D (1997) Amino Acids 13:355-367

118. Prudent M, Rossier JS, Lion N, Girault HH (2008) Anal Chem 80:2531-2538

119. Van Berkel GJ, Zhou F, Aronson JT (1997) Int J Mass Spectrom Ion Process 162:55-67

120. Zhou S, Edwards AG, Cook KD, Van Berkel GJ (1999) Anal Chem 71:769-776

121. Pan P, Gunawardena HP, Xia Y, McLuckey SA (2004) Anal Chem 76:1165-1174

122. Leitner A, Lindner W (2004) J Chromatogr B 813:1-26

123. Nakazawa T (2006) Curr Proteomics 3:33-54

124. Leitner A, Lindner W (2006) Proteomics 6:5418-5434

125. Sokolovsky M, Riordan JF, Vallee BL (1967) Biochem Biophys Res Commun 27:20-25

126. Balabanli B, Kamisaki Y, Martin E, Murad F (1999) Proc Natl Acad Sci USA 96:13136-13141

127. Ohshima H, Celan I, Chazotte L, Pignatelli B, Mower HF (1999) Nitric Oxide 3:132-141
128. Sodum RS, Akerkar SA, Fiala ES (2000) Anal Biochem 280:278-285

129. Ishida N, Hasegawa T, Mukai K, Watanabe M, Nishino H (2002) J Vet Med Sci 64:401-404

130. Richards DA, Silva MA, Devall AJ (2006) Anal Biochem 351:77-83

131. Nikov G, Bhat V, Wishnok JS, Tannenbaum SR (2003) Anal Biochem 320:214-222

132. Sharov VS, Dremina ES, Pennington J, Killmer J, Asmus C, Thorson M, Hong SJ, Li X, Stobaugh JF, Schoneich C (2008) Methods Enzymol 441:19-32

133. Detweiler CD, Lardinois OM, Deterding LJ, de Montellano PRO, Tomer KB, Mason RP (2005) Free Radic Biol Med 38:969-976

134. Deterding LJ, Lhattacharjee S, Ramirez DC, Mason RP, Tomer KB (2007) Anal Chem 79:6236-6248

135. Gomez-Mejiba SE, Zhai Z, Akram H, Deterding LJ, Hensley K, Smith N, Tomer RA, Tomer KB, Mason RP, Ramirez DC (2009) Free Radic Biol Med 46:853-865

136. Burzio LA, Waite JH (2001) Protein Sci 10:735-740

137. Reddie KG, Carroll KS (2008) Curr Opin Chem Biol 12:746-754

138. Hutinec A, Ziogas A, Rieker A (1996) Amino Acids 11:345-366

139. Compagnini A, Cunsolo V, Foti S, Saletti R (2001) Eur J Mass Spectrom 7:123-130

140. Wu W, Chen Y, d'Avignon A, Hazen SL (1999) Biochemistry 38:3538-3548

141. Gevaert K, Pinxteren J, Demol H, Hugelier K, Staes A, Van Damme J, Martens L, Vandekerckhove J (2006) J Proteome Res 5:1415-1428

142. Eichacker LA, Granvogl B, Mirus O, Müller BC, Miess C, Schleiff E (2004) J Biol Chem 279:50915-50922

143. Dayon L, Girault HH (2007) Anal Bioanal Chem 389:841-849

144. Chowdhury SK, Katta V, Chait BT (1990) J Am Chem Soc 112:9012-9013

145. Loo JA, Edmonds CG, Udseth HR, Smith RD (1990) Anal Chem 62:693-698

146. Kaltashov IA, Eyles SJ (2002) Mass Spectrom Rev 21:37-71

147. Konermann L, Stocks BB, Pan Y, Tong X (2009) Mass Spec Rev. doi:10.1002/mas.20256

148. Bridgewater JD, Srikanth R, Lim J, Vachet RW (2007) J Am Soc Mass Spectrom 18:553-562

149. Hung CW, Schlosser A, Wei JH, Lehmann WD (2007) Anal Bioanal Chem 389:1003-1016

150. Men L, Wang Y (2005) Rapid Commun Mass Spectrom 19:23-30

151. Paizs B, Suhai S (2005) Mass Spectrom Rev 24:508-548

152. Sullivan AG, Brancia FL, Tyldesley R, Bateman R, Sidhu K, Hubbard SJ, Oliver SG, Gaskell SJ (2001) Int J Mass Spectrom 210:665-676

153. Syka JEP, Coon JJ, Schroeder MJ, Shabanowitz J, Hunt DF (2004) Proc Natl Acad Sci USA 101:9528-9533

154. Liu ZJ, Julian RR (2009) J Am Soc Mass Spectrom 20:965-971

155. Steen H, Mann M (2002) Anal Chem 74:6230-6236

156. Mirzaei H, Brusniak M-Y, Mueller LN, Letarte S, Watts JD, Aebersold R (2009) Mol Cell Proteomics 8:1934-1946

157. Hernandez H, Niehauser S, Boltz SA, Gawandi V, Phillips RS, Amster IJ (2006) Anal Chem 78:3417-3423

158. Yao XD, Diego P, Ramos AA, Shi Y (2008) Anal Chem 80:7383-7391

159. Thompson A, Schäfer J, Kuhn K, Kienle S, Schwarz J, Schmidt G, Neumann T, Hamon C (2003) Anal Chem 75:1895-1904

160. Ross PL, Huang YN, Marchese JN, Williamson B, Parker K, Hattan S, Khainovski N, Pillai S, Dey S, Daniels S, Purkayastha S, Juhasz P, Martin S, Bartlet-Jones M, He F, Jacobson A, Pappin DJ (2004) Mol Cell Proteomics 3:1154-1169

161. Gygi SP, Rist B, Gerber SA, Turecek F, Gelb MH, Aebersold R (1999) Nat Biotechnol 17:994-999 
162. Kuyama H, Makoto W, Chikako T, Eiji A, Koichi T, Osamu N (2003) Rapid Commun Mass Spectrom 17:1642-1650

163. Chen M, Cook KD (2007) Anal Chem 79:2031-2036

164. Gevaert K, Impens F, Ghesquiere B, Van Damme P, Lambrechts A, Vandekerckhove J (2008) Proteomics 8:4873-4885

165. Galas DJ, Schmitz A (1978) Nucleic Acids Res 5:3157-3170

166. Engen JR (2009) Anal Chem 81:7870-7875

167. Sheshberadaran H, Payne LG (1988) Proc Natl Acad Sci USA $85: 1-5$

168. Heyduk E, Heyduk T (1994) Biochemistry 33:9643-9650

169. Zhong M, Lin L, Kallenbach NR (1995) Proc Natl Acad Sci USA 92:2111-2115

170. Sharp JS, Becker JM, Hettich RL (2003) Anal Biochem 313:216225

171. Takamoto K, Chance MR (2006) Annu Rev Biophys Biomol Struct 35:251-276
172. Brabec V, Bianco P, Haladjian J (1982) Biophys Chem 16:51-59

173. Maleknia SD, Mark RC, Kevin MD (1999) Rapid Commun Mass Spectrom 13:2352-2358

174. Gaut JP, Byun J, Tran HD, Heinecke JW (2002) Anal Biochem 300:252-259

175. Petersson AS, Steen H, Kalume DE, Caidahl K, Roepstorff P (2001) J Mass Spectrom 36:616-625

176. Salek M, Lehmann WD (2005) Proteomics 5:351-353

177. Guan ZQ, Yates NA, Bakhtiar R (2003) J Am Soc Mass Spectrom 14:605-613

178. Schmidt F, Krah A, Schmid M, Jungblut PR, Thiede B (2006) Rapid Commun Mass Spectrom 20:933-936

179. Steen H, Mann M (2001) J Am Soc Mass Spectrom 12:228232

180. Yagüe J, Antonio N, Manuel B, Manel E, Patricia A, Casal JI (2005) Proteomics 5:2761-2768 